\title{
Exploring Potable Groundwater Sources Surrounding Manchar Lake
}

\author{
Sultan Shaikh $^{1 \mathrm{a}, 2}$, Uzma Imran ${ }^{1 \mathrm{~b}}$, Zamir Ahmed Soomro ${ }^{2 b}$ \\ RECEIVED ON 27.04.2019, ACCEPTED ON 16.12.2020
}

\begin{abstract}
This study was carried out to explore the groundwater quality in Manchar Lake's surroundings, (one of Asia's largest lakes in Sindh Province of Pakistan), to discover sites where potable groundwater is available. To achieve this objective, Vertical Electrical Sounding (VES) was employed at 21 sites in shallow depths by adopting Schlumberger electrode array alignment. The maximum distance chosen between current electrodes $(A \&$ B) was $300 \mathrm{~m}$, and $20 \mathrm{~m}$ was between potential electrodes (M \& N). ABEM terrameter SAS 4000 and IX1D resistivity software was used for data collection and interpretation, respectively. The results revealed that except for two sites (13 and 19), all other sites do not have potable groundwater at any depth. At site 13, one out of three layers lies under a high resistivity zone, while at site 19, two out of four layers lie under a high resistivity zone, which indicates the presence of potable water. To verify VES findings, water samples from 5 trial bores made by hand percussion method were collected and analyzed for Electrical Conductivity (EC) and Total Dissolved Solids (TDS), which revealed saline water from all trial bores. To sum up, potable groundwater is not available in the vicinity of Manchar Lake at shallow depths.
\end{abstract}

Keywords: Vertical Electrical Survey, Groundwater Quality, Manchar Lake

\section{INTRODUCTION}

$\mathrm{T}$ The necessity for the quality and accessibility of water assets has consistently been the main concern of our societies particularly in semiarid and arid regions. The matter of obtaining enough supply of potable water is main issue nowadays due to consistently expanding of population, irrigation, industrialization and dumping of untreated effluents in the freshwater resources. Because of these circumstances, another alternative i.e. groundwater must be searched so that people can get potable water [1]. The community near Manchar Lake (one of the Asia's major lake, located near Sehwan in Sindh Province of Pakistan) is one such place that needs alternative source of warer (groundwater) for drinking purpose because Manchar lake water is contmainated with various toxic and heavy metals [2] and is unfit for drinking. Because of an absence of other drinking water sources, individuals close to lake are constrained to use its contaminated water, which results in poor health impacts. Furthermore, according to World Health Organization (WHO-1998), the groundwater in the region of the lake is too salty to even consider for drinking. While numerous investigations have been led to assess the water quality of Manchar Lake [4-7], no examination has been led to investigate the groundwater quality in the region of the lake [3]. Therefore, this study investigates consumable groundwater encompassing Manchar Lake utilizing an electrical resistivity survey.

Globally many studies have been conducted to explore

\footnotetext{
${ }^{1}$ Institute of Environmental Engineering, US-Pakistan Centre for Advanced Studies in Water (USPCASW), Mehran University of Engineering and Technology, Jamshoro, Sindh, Pakistan.

Email: ${ }^{\mathrm{a}}$ sultanshaikhmuet@ gmail.com (Corresponding Author), ${ }^{\mathrm{b}}$ uimran.uspcasw@ faculty.muet.edu.pk ${ }^{2}$ Pakistan Council of Research in Water Resources (PCRWR) Lahore. Email: bengrsaz@gmail.com This is an open access article published by Mehran University of Engineering and Technology, Jamshoro under CC BY 4.0 International License.
} 
groundwater quality using electrical resistivity survey [8]. In Pakistan, on the other hand, very few studies have explored groundwater quality [9]. One study conducted in Nigeria bears a similar scope to the present inquiry. In the community of Kwale near the Niger River, Oseji et al. [10] utilized Vertical Electrical Sounding (VES) to examine different features of aquifer and potential of groundwater. The goal of their investigation was to investigate groundwater for household and indutrial purposes, which recently used River Niger water for household water needs. However, the Niger River water is currently unfit for human utilization because of expanding industrialization. This scenario is similar to that of Manchar Lake.

VES has proven an effective technique for the investigation of groundwater. In an exploration of groundwater quality, Sikandar [11] inferred that the VES could be utilized successfully to identify subsurface aquifer layers and to describe the salinity of groundwater.

Since VES plays a vital role in the determination of groundwater quality, there are a few limitations of electrical resistivity surveys, including:
- Like vevery single geophysical technique, resistivity information is indistinct; various models can create similar information.

- For measurement we have to insert electrodes into the ground which makes resistivity process slow.

- The ERS information is influenced by surface conductive layers. Along highly conductive layers, current moves all around effectively. If the surface where ERS is conducted is highly conductive, it may not be practical to gather information beneath that layer [12].

Therefore, in this research, VES is adopted in a shallow depth grid $\left(5 \times 5 \mathrm{~km}^{2}\right)$ for the investigation of groundwater quality. To validate VES findings, trial bores are constructed where water samples are collected and examined for Electrical Conductivity (EC) and Total Dissolved Solids (TDS).

\section{MATERIALS AND METHODS}

\subsection{Site Selection}

The locations where VES was conducted were nominated randomly in the surrounding area of the Manchar Lake. However, to validate VES findings, trial bores were constructed on five sites (see Fig. 1).

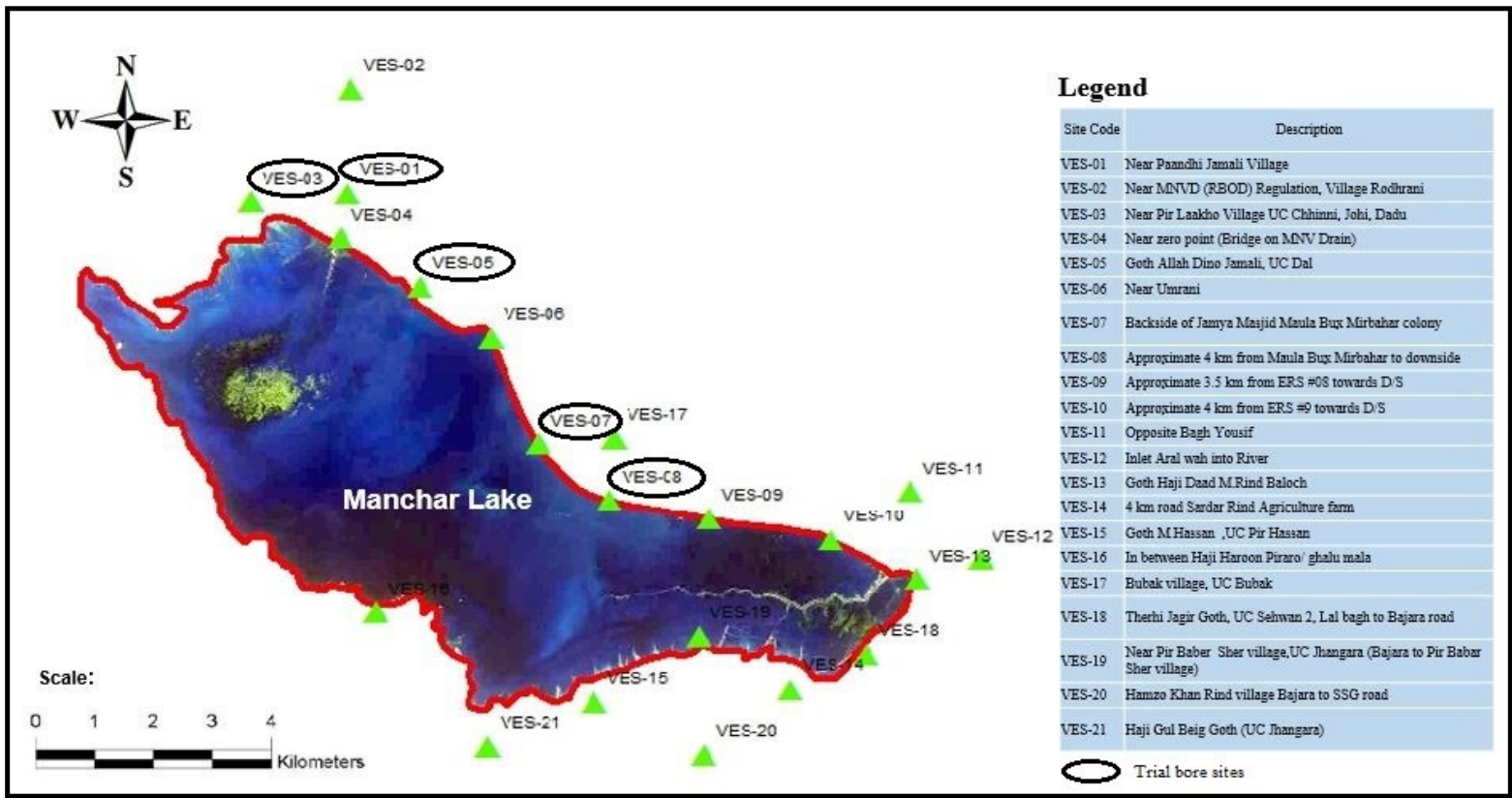

Fig. 1: Vertical electrical sounding sites 


\subsection{Instruments Used}

The terrameter SAS 4000 (ABEM, Sweden) was used for conducting VES. Other accessories with the terrameter included two measuring tapes, two large wires (A - B), two small wires $(\mathrm{M}-\mathrm{N})$, data forms, four metal electrodes, two hammers, an external battery source, an external battery connector, walkie talkies, a calculator and connecting cables [13, 14].

\subsection{Electrode Configuration}

The arrangement of electrodes while measuring resistivity is known as electrode array [15]. Different electrode array arrangements are available, such as Pole-Pole, Dipole-Dipole, Pole-Dipole, Schlumberger and Wenner array, but the Schlumberger array is found to be the most appropriate and suitable among all of these arrangements for groundwater exploration [16]. In this research, most commonly used Schlumberger electrode array was adopted; it includes $\mathrm{A}$ and $\mathrm{B}$ current electrodes, and $\mathrm{M}$ and $\mathrm{N}$ potential electrodes which are placed outside and inside, respectively in one straight line (see Fig. 2).

To increase depth range, the position of current elctrodes is changed to a new position while the position of potential electrodes remain unchanged. When the distance between current and potential electrodes becomes too wide then position of potential elctrodes must also be changed. Otherwise, the potential difference becomes too small to be measured with sufficient accuracy [14].

\subsection{Electrical Resistivity Survey (ERS)}

ERS is classified into Vertical Electrical Sounding (VES) and horizontal profiling [18]. The VES technique is designed to solve groundwater problems such as determination of the line between saline and freshwater zones [12,19], as well as aquifer thickness, depth, and limit [20,21]. Furthermore, VES aids in the evaluation of groundwater quality [22, 23] and exploration of geothermal reservoirs [24]. In this study, VES is implemented for the exploration of groundwater quality. It has been verified as a traditional method due to its smooth field operation, availability of the equipment, less filling pressure, greater depth of penetration, and is manageable by modern computers [9]. The VES involves passing an electrical current into the ground through two current electrodes; the resulting potentials created in the field are measured through two potential electrodes [25]. The maximum half distance between two current electrodes $(\mathrm{AB} / 2)$ is set to $300 \mathrm{~m}$, whereas the maximum half distance between potential electrodes (MN/2) is set to $20 \mathrm{~m}$ as adopted by [13]. The distance between current electrodes is proportional to the distance, as you increase the distance between current electrodes, it means you are going deeper in depth [13]. In this study, we are intrested in $1000 \mathrm{ft}$ depth, therefore the maximum half distance between current electrodes is adopted as $300 \mathrm{~m}$. However, MN/2 distance is always kept small as relative to $A B / 2$, and is changed only when the observed voltage becomes too small to measure [28]. Therefore, in this study it is adoped as $20 \mathrm{~m}$.

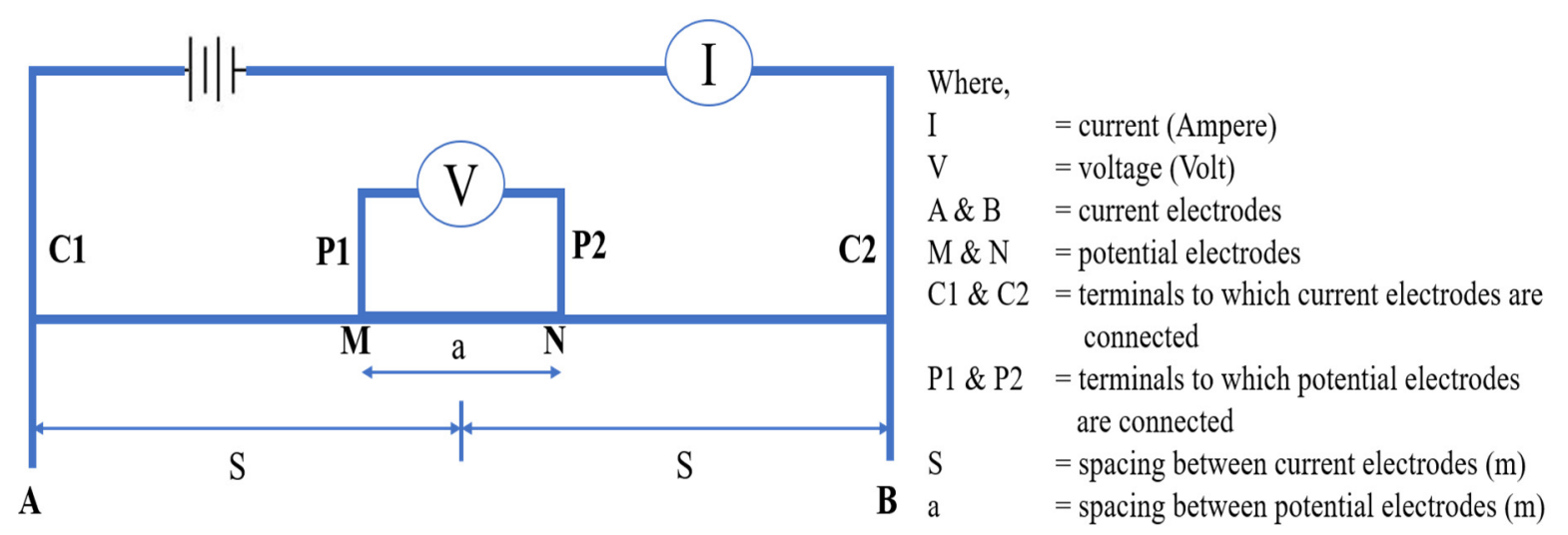

Fig. 2: Geometric Arrangement of the Schlumberger Array Configuration [17] 


\subsection{Procedure}

- An ABEM SAS terameter was placed halfway between the potential electrodes, and P1 and P2 terminals were connected to the terminals $\mathrm{M}$ and $\mathrm{N}$, respectively.

- The current electrodes-namely A and B are attached to the $\mathrm{C} 1$ and $\mathrm{C} 2$ terminals, respectively.

- The current and potential electrodes were driven at their respective position into the ground with hammers.

- Resistivity mode was set, if it is not set.

- The selected method was sounding and the layout was Schlumberger.

- The measuring knob was activated for performing measurements.

- Proceeded to next position for next measurement. [26].

The data obtained from the Terrameter was resistivity $(\mathrm{V} / \mathrm{I})$ and apparent resistivity $\left(\rho_{\mathrm{a}}\right)$, calculated by Ohm's Law (equation (1)).

Apparent Resistivity $=\mathrm{K} \times(\mathrm{V} / \mathrm{I})$

where $\mathrm{K}=$ Geometric factor and is calculated by Equation (2).

$\mathrm{K}=\frac{\pi\left\{(\mathrm{AB})^{2}-(\mathrm{MN} / 2)^{2}\right\}}{\mathrm{MN}}$

where $A B / 2$ shows half spacing of current electrodes (m) and MN/2 shows half spacing of potential electrodes $(\mathrm{m})$ and $\mathrm{MN}$ is the total distance between potential electrodes [13].

\subsection{Trial Bores}

Trial bores were drilled using the hand percussion method up to $100 \mathrm{ft}$. depth, from where samples were collected at intervals of approximately $10 \mathrm{ft}$. Due to financial constraints, the bores were drilled up to 100 $\mathrm{ft}$. depth, whereas, to make interval distance uniform, the samples were collected at $10 \mathrm{ft}$. interval. The collected samples were transported to the laboratory of the Pakistan Council of Research in Water Resources (PCRWR) in Karachi for analysis.

\subsection{Analysis of Survey Data}

The data obtained from vertical electrical sounding The data obtained from vertical electrical sounding was interpreted by IX1D software. The resistivity models were produced by fitting acquired data with the least root mean square error $(<5 \%)$ between the data generated by the models and the real data.

\section{RESULTS AND DISCUSSION}

\subsection{VES Results}

\section{VES-01 (Near Paandhi Jamali Village)}

The study area is divided into four resistivity zones depending on the field geology [9] as low (0-5 ohm$\mathrm{m})$, medium (5-15 ohm-m), high (15-50 ohm-m), and very high ( $>50 \mathrm{ohm}-\mathrm{m})$ (see Table 2 ). At site VES-01, a total of four layers were discovered. The top two layers were in the low resistivity zones with values of $4.7 \mathrm{ohm}-\mathrm{m} \& 2.6 \mathrm{ohm}-\mathrm{m}$ at a depth of 1.3 and $11.3 \mathrm{~m}$, respectively. These two layers were underlain by other low resistivity layers with resistivity values of 4.74 ohm-m up to a depth of $77.8 \mathrm{~m}$ and 1.9 ohm-m up to an infinite depth (see Fig. 3).

At site 1 all layers lie in the zone of low resistivity values which indicates fine material such as clay and sand along with presence of salty water (see Table 2).

\section{VES -03 (Near Peer Laakho Village UC Chhinni, Johi, Dadu)}

At site 3, a total of four layers were discovered with the first layer lying in a medium resistivity zone, which indicates the presence of intermediate sand with some clay; meanwhile, the last three layers lie in a low resistivity zone, which indicates the presence of saline or less saline groundwater (see Fig. 4). The first layer has a resistivity value of $5.23 \mathrm{ohm}-$ $\mathrm{m}$ up to a depth of $1.39 \mathrm{~m}$. The second layer has a resistivity value of $1.56 \mathrm{ohm}-\mathrm{m}$ up to a depth of 10.40 $\mathrm{m}$, which is underlain by two other low resistivity layers with resistivity values of 2.75 and $0.96 \mathrm{ohm}-\mathrm{m}$. The third layer has a depth of $31.5 \mathrm{~m}$ and the last layer was found to have an infinite depth (see Table 1 and 2).

\section{VES -05 (Goth Allah Dino Jamali, UC Dal)}

Site 5 consisted of four layers lying within the low resistivity zone, which indicate fine material with the presence of saline water (Fig. 5). The resistivity values of the top two layers were $4.84 \mathrm{ohm}-\mathrm{m}$ to a depth of 
$1.43 \mathrm{~m}$ and $3.24 \mathrm{ohm}-\mathrm{m}$ up to a depth of $15.6 \mathrm{~m}$. The bottom two layers, one with a depth of $145 \mathrm{~m}$, showed resistivity of $1.56 \mathrm{ohm}-\mathrm{m}$, while the other had an infinite depth with $1 \mathrm{ohm}-\mathrm{m}$ resistivity (see Table 1 and 2).

VES -07 (Backside of Jamya Masjid Maula Bux Mirbahar colony)

At site 7, a total of four layers were discovered. The top three layers lie in low resistivity zones with resistivity values of $0.58,1.68$ and $1.97 \mathrm{ohm}-\mathrm{m}$ up to a depth of $0.14,7.4$ and $18.6 \mathrm{~m}$., respectively. However, the bottom layer lies in a medium resistivity zone with an infinite depth and a resistivity value of $6.4 \mathrm{ohm}-\mathrm{m}$ (see Table 1 and 2). The fact that the first three layers lie in low resistivity zones indicates that saline groundwater is available up to a depth of $60 \mathrm{ft}$. However, the last layer lies in a medium resistivity zone, which indicates the presence of intermediate sand with some clay (see Fig. 6).

\begin{tabular}{|c|c|c|c|}
\hline \multicolumn{4}{|c|}{ Table 1: Detail of strata depth with resistivity } \\
values of all VES sites \\
\hline Site & Type of soil & Depth & R $(\boldsymbol{\Omega}$-m) \\
\hline VES-01 & Clay/shale & 1.3561 & 4.7006 \\
\cline { 2 - 4 } & Clay/shale & 11.324 & 2.6762 \\
\cline { 2 - 4 } & Clay/shale & 77.802 & 4.7429 \\
\cline { 2 - 4 } & - & - & 1.9636 \\
\hline VES-03 & Sand Clay & 1.3964 & 5.2354 \\
\cline { 2 - 4 } & Clay/shale & 10.408 & 1.5695 \\
\cline { 2 - 4 } & Clay/shale & 31.577 & 2.7502 \\
\cline { 2 - 4 } & - & - & 0.96099 \\
\hline VES-05 & Clay/shale & 1.4325 & 4.8459 \\
\cline { 2 - 4 } & Clay/shale & 15.696 & 3.2416 \\
\cline { 2 - 4 } & Clay/shale & 145.05 & 1.5669 \\
\cline { 2 - 4 } & - & - & 1.0282 \\
\hline VES-07 & Clay/shale & 0.14629 & 0.58153 \\
\cline { 2 - 4 } & Clay/shale & 7.4629 & 1.6847 \\
\cline { 2 - 4 } & Clay/shale & 18.689 & 1.9715 \\
\cline { 2 - 4 } & - & - & 6.4764 \\
\hline VES-08 & Clay/shale & 4.9295 & 2.6758 \\
\cline { 2 - 4 } & Clay/shale & 47.413 & 3.9767 \\
\cline { 2 - 4 } & - & - & 0.90974 \\
\hline
\end{tabular}

\begin{tabular}{|c|c|c|}
\hline \multicolumn{3}{|c|}{ Table 2: Correlation between resistivity ranges and hydrogeology for investigated area [9,27] } \\
\hline $\begin{array}{c}\text { Resistivity } \\
\text { Zone }\end{array}$ & $\begin{array}{c}\text { Resistivity } \\
\text { (ohm-m) }\end{array}$ & Relationship between geological formation and water content quality \\
\hline Low & $0-5$ & $\begin{array}{r}\text { It indicates fine materials like clay/shale, with rare sand and } \\
\text { consequently having salty water potential. }\end{array}$ \\
\hline Medium & $5-15$ & $\begin{array}{c}\text { This zone demonstrates the existence of mixture of sand with some clay. } \\
\text { It might likewise demonstrate the presence of alternate bedding of sand } \\
\text { and clay/shale. The arrangement can yield groundwater if underneath } \\
\text { the water table. }\end{array}$ \\
\hline High & $15-50$ & $\begin{array}{c}\text { This zone indicates existence of coarser material i.e., sand with good } \\
\text { quality of groundwater }\end{array}$ \\
\hline Very High & $>50$ & $\begin{array}{c}\text { High value of resistivity indicates existence of unsaturated zone and } \\
\text { bedrock if above and below the water table respectively }\end{array}$ \\
\hline
\end{tabular}
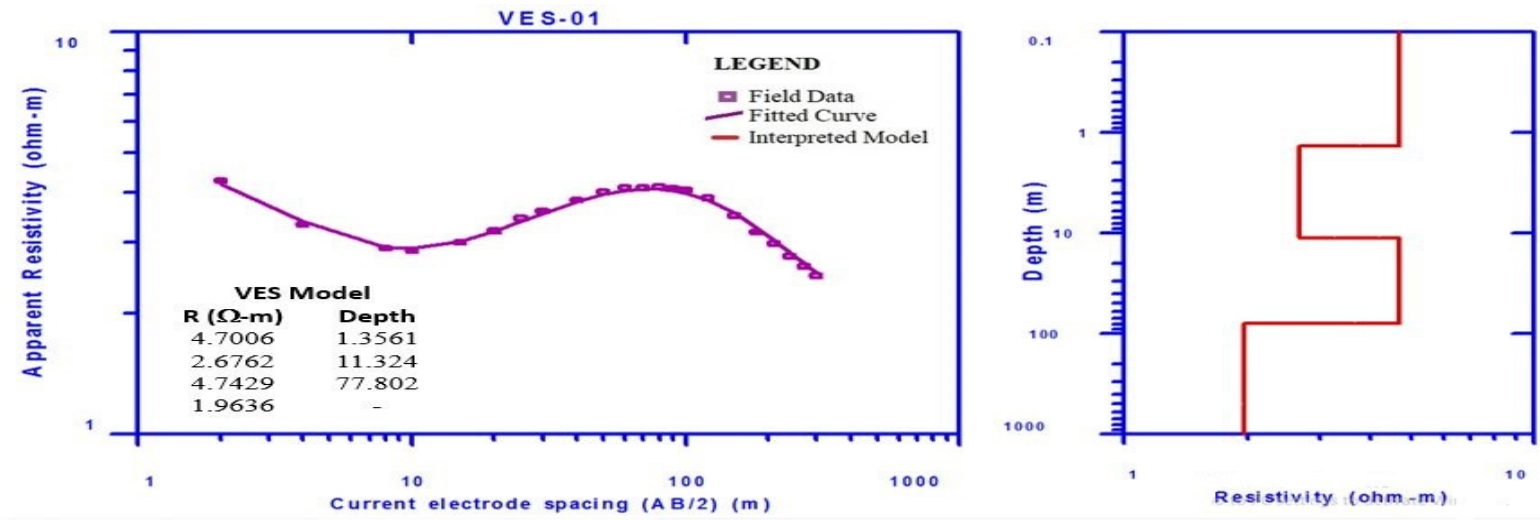

Fig. 3: 1D resistivity model of VES - 01 developed in IX1D resistivity software 

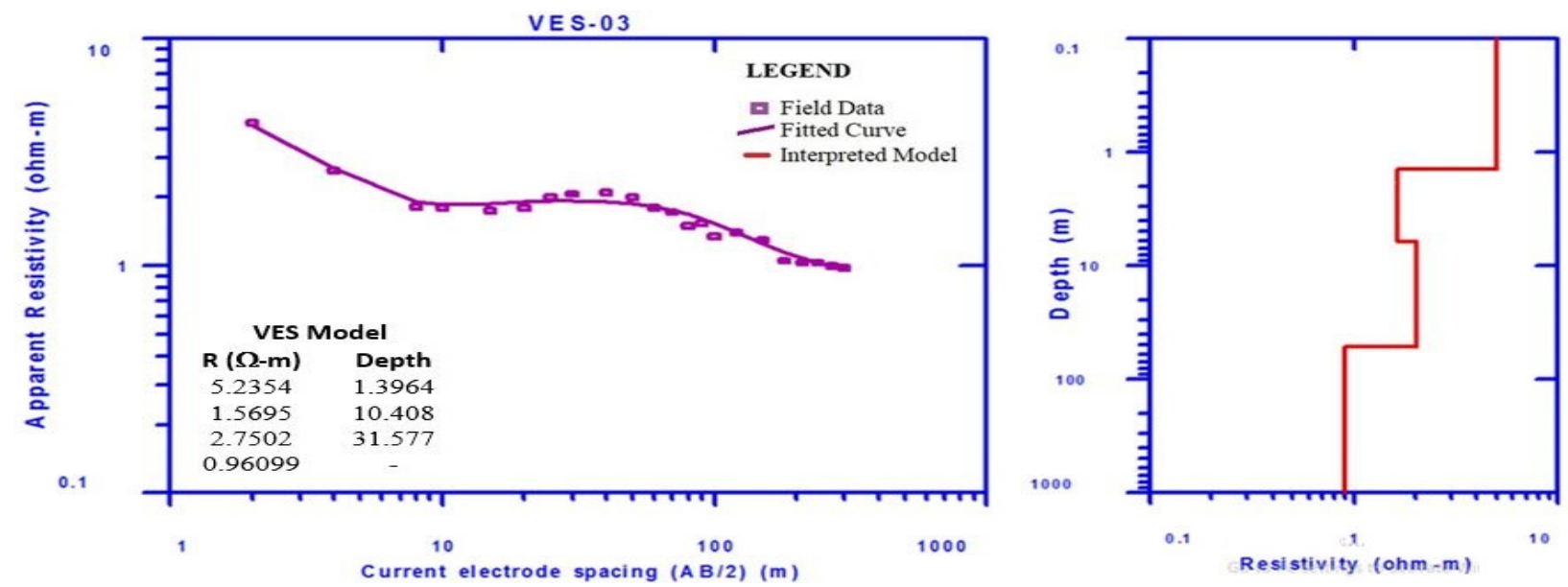

Fig. 4: 1D resistivity model of VES - 03 developed in IX1D resistivity software
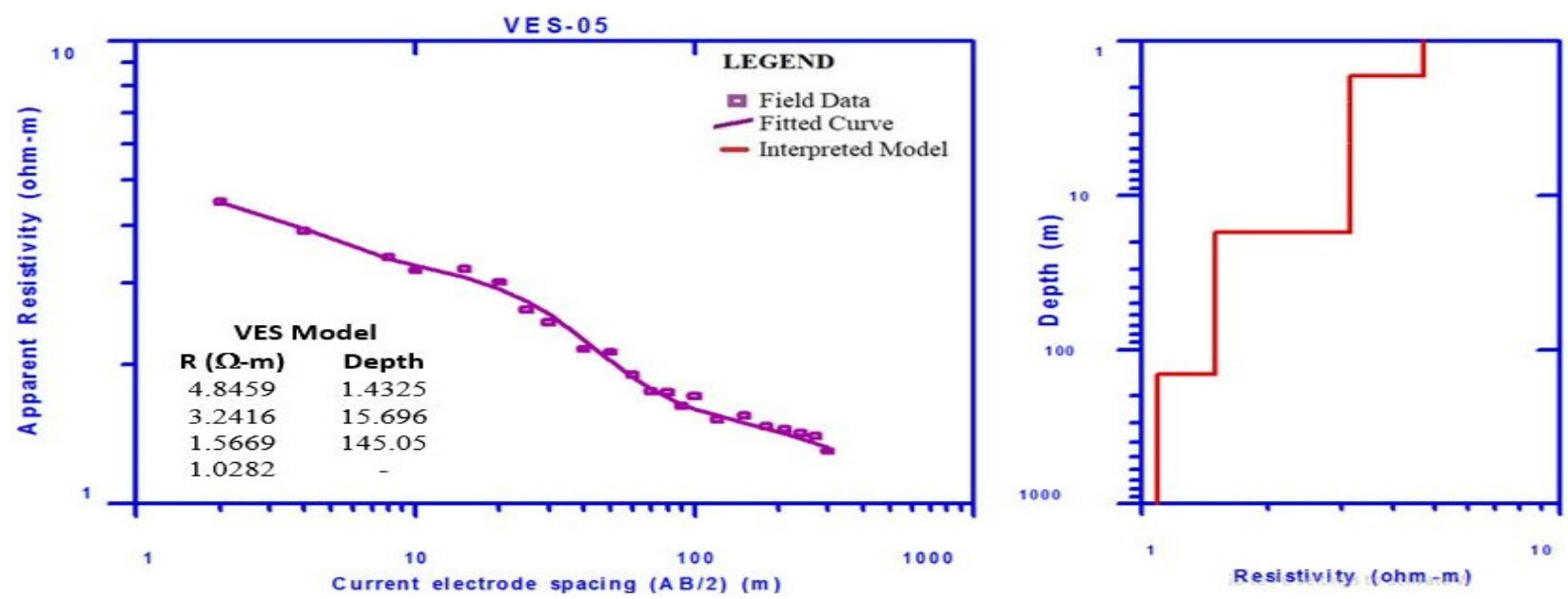

Fig. 5: 1D resistivity model of VES - 05 developed in IX1D resistivity software
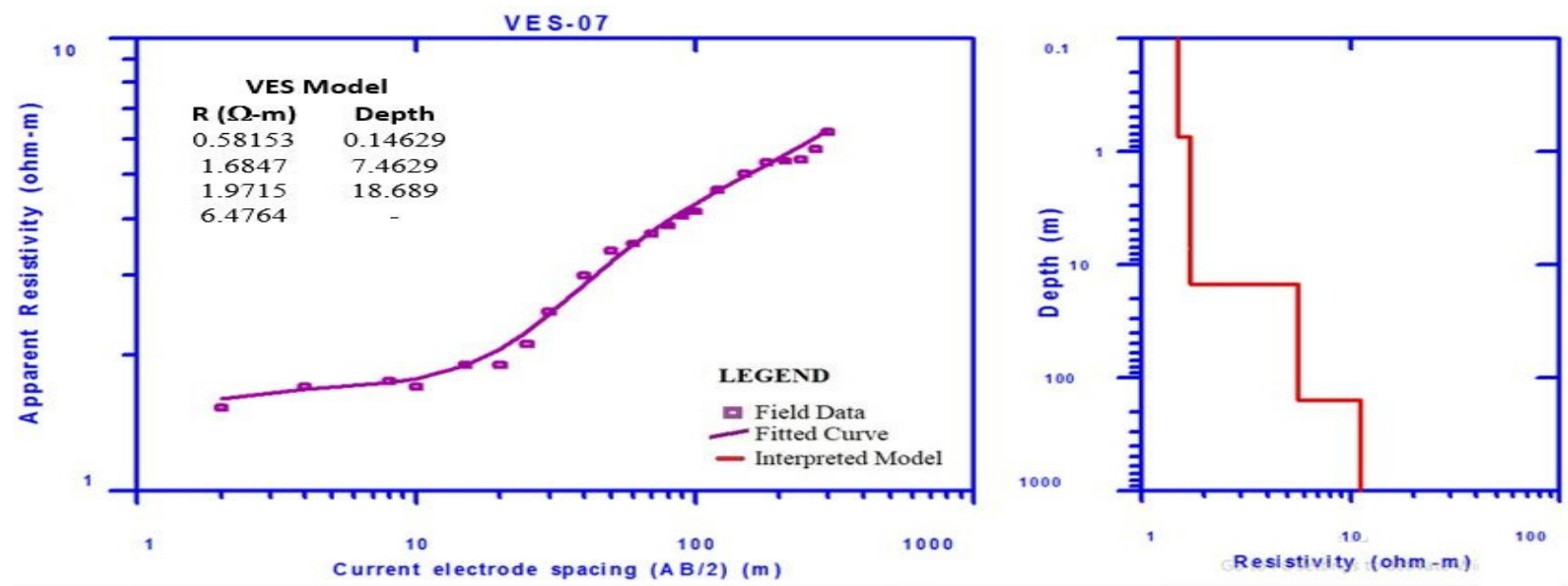

Fig. 6: 1D resistivity model of VES - 07 developed in IX1D resistivity software 

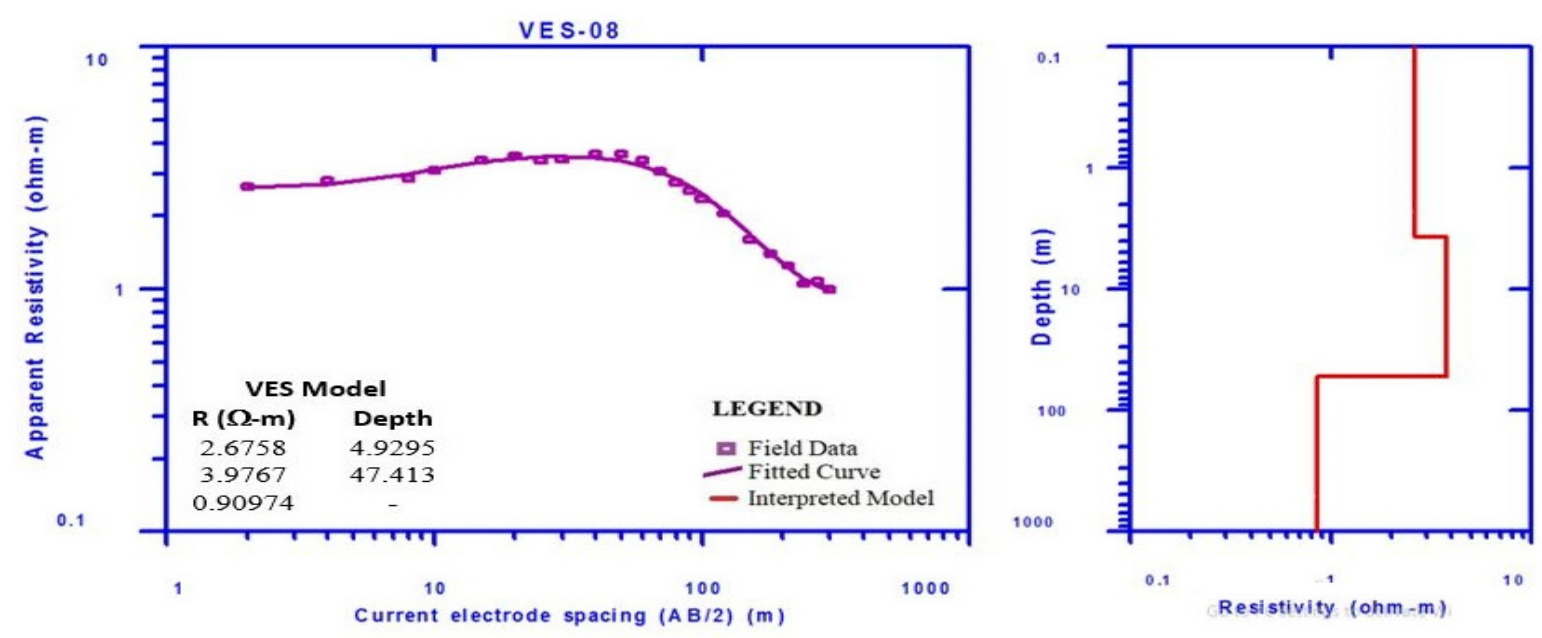

Fig. 7: 1D resistivity model of VES - 08 developed in IX1D resistivity software

VES -08 (Approximate $4 \mathrm{~km}$ from Maula Bux Mirbahar to the downside)

At site 8, three layers of low resistivity were discovered. The resistivity of the top, middle, and bottom layers were 2.6, 3.9 and $0.90 \mathrm{ohm}-\mathrm{m}$., respectively. The depth of the top two layers was found to be 4.92 and $47.4 \mathrm{~m}$, and both layers were underlain by layer with infinite depth (see Table 1 and 2). The resistivity of all the layers was less than $5 \mathrm{ohm}-\mathrm{m}$., which indicates the existence of saline water (see Fig. 7).

\subsection{Correlation between VES data and bore data}

\section{VES-01 and Trial Bore-1}

At site VES-01, a total of four layers were found. Every one of the four layers have a resistivity underneath $5 \mathrm{ohm}-\mathrm{m}$, i.e., all layers lie in a low resistivity zone. A low resistivity zone indicates the existence of finely ground materials, such as clay/shale, with rare sand. Consequently, the site has saline to less saline water-bearing potential (see table 2). On the other hand, the textural examination of the soil collected from the trial bore-1 shows three layers of soil up to $100 \mathrm{ft}$. in depth (see Table 4). In this way, the VES information adjusts well to the bore information. The water quality obtained from trial bore- 1 at different depths is saline because it has high EC and total dissolved solids (see Table 3). This data again demonstrates the high correlation between VES01 and the trial bore- 1 data.

\section{VES-03 \& Trial Bore-2}

Similarly, to site 1 , at site VES-03, four layers were discovered. The first layer lies in the medium resistivity zone and the last three layers lie in the low resistivity zone. The medium resistivity zone indicates the presence of intermediate sand with some clay. It may also indicate the presence of alternate bedding of sand and clay/shale. Similarly, the low resistivity zone indicates the presence of finely ground materials such as clay/shale, with rare sand. Therefore, the site has saline to less saline water-bearing potential. The analysis of soil collected from trial bore- 2 shows five layers of soil (silt loam, loam, sandy loam, silt loam, and sandy loam) up to $100 \mathrm{ft}$. depth (see Table 5). Therefore, the data from the trial bore soil has a high correlation with the VES data. The water obtained from trial bore-2 has high EC and TDS, which shows that water is saline in nature (see Table 3). This data again demonstrates the high correlation between VES03 and the trial bore- 2 data.

\section{VES-07 and Trial Bore-3}

At site VES-07, a total of four layers were discovered. The top three layers lie in the low resistivity zone and the bottom layer lies in the medium resistivity zone. A low resistivity zone indicates the presence of finely ground materials, such as clay/shale, with rare sand. Therefore, the site has saline to less saline waterbearing potential. Similarly, the medium resistivity zone indicates the presence of intermediate sand with some clay. It may also indicate the presence of

Mehran University Research Journal of Engineering and Technology, Vol. 40, No. 4, October 2021 [p-ISSN: 0254-7821, e-ISSN: 2413-7219] 
alternate bedding of sand and clay/shale. However, the textural analysis of soil collected from trial bore-3 shows two layers of soil (silty loam and sandy loam) up to $100 \mathrm{ft}$. in depth (see Table 6). Therefore, the data from the trial bore soil has a high correlation with the VES data. The water collected from trial bore-3 is salty, which is revealed from high EC and TDS values (see Table 3). This data again demonstrates alignment between VES-07 and the trial bore-3 data.

\section{VES-05 and Trial Bore-4}

At site VES-05, four layers were discovered, all of which have a resistivity less than 5 ohm-m, which indicates that all layers lie in a low resistivity zone. A low resistivity zone indicates the presence of finely ground materials, such as clay/shale with rare sand. Therefore, the site has saline to less saline waterbearing potential. The textural analysis of the soil collected from trial bore-4 shows six layers of soil (sandy clay loam, silty clay loam, clay, sandy clay, silty clay and silty loam) up to $100 \mathrm{ft}$. in depth (see Table 7). Therefore, the data from the trial bore soil has low correlation with the VES data. The water obtained from trial bore-4 has high EC and TDS, which results in brackish water (see Table 3). This data demonstrates high correlation between VES-07 and the trial bore- 4 water data.

\begin{tabular}{|c|c|c|c|c|c|c|c|c|c|}
\hline \multirow{2}{*}{\multicolumn{10}{|c|}{ 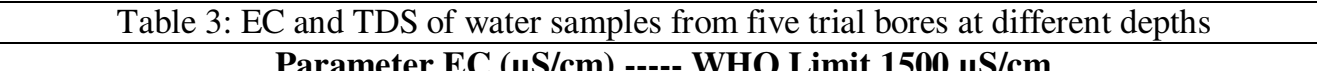 }} \\
\hline & & & & & & & & & \\
\hline \multicolumn{2}{|c|}{ Bore-1 } & \multicolumn{2}{|c|}{ Bore-2 } & \multicolumn{2}{|c|}{ Bore-3 } & \multicolumn{2}{|c|}{ Bore-4 } & \multicolumn{2}{|c|}{ Bore-5 } \\
\hline Depth & Value & Depth & Value & Depth & Value & Depth & Value & Depth & Value \\
\hline 30 & 17120 & 30 & 15410 & 20 & 18210 & 20 & 5500 & 20 & 3760 \\
\hline 40 & 5000 & 40 & 16050 & 30 & 11910 & 30 & 4390 & 30 & 4410 \\
\hline 50 & 3650 & 60 & 15070 & 50 & 10570 & 40 & 6380 & 40 & 3750 \\
\hline 60 & 8600 & 70 & 16550 & & & 50 & 6250 & & \\
\hline 70 & 6110 & 80 & 19040 & & & 60 & 11300 & & \\
\hline 80 & 9640 & & & & & 70 & 29100 & & \\
\hline 90 & 9040 & & & & & 80 & 35800 & & \\
\hline \multicolumn{10}{|c|}{ Parameter TDS (ppm) ----- WHO Limit 1000 ppm } \\
\hline 30 & 10956 & 30 & 9862 & 20 & 11654 & 20 & 3575 & 20 & 2444 \\
\hline 40 & 3200 & 40 & 10272 & 30 & 7622 & 30 & 2854 & 30 & 2866 \\
\hline 50 & 2336 & 60 & 9644 & $\mathbf{5 0}$ & 6764 & 40 & 4147 & 40 & 2438 \\
\hline 60 & 5504 & 70 & 10592 & & & $\mathbf{5 0}$ & 4062 & & \\
\hline 70 & 3910 & 80 & 12185 & & & 60 & 7345 & & \\
\hline 80 & 6169 & & & & & 70 & 18195 & & \\
\hline 90 & 5785 & & & & & 80 & 23270 & & \\
\hline
\end{tabular}

\begin{tabular}{|c|c|c|c|c|c|}
\hline \multicolumn{7}{|c|}{ Table 4: Soil texture of Trial Bore-1 } \\
\hline Depth (ft.) & \multicolumn{5}{c|}{ Soil Texture } \\
\hline & Silt +Clay & Sand\% & Silt\% & Clay\% & Texture Class \\
\hline 10 & 77.6 & 22.4 & 62 & 15.6 & Silt Loam \\
\hline 20 & 78.8 & 21.2 & 57.2 & 21.6 & Silt Loam \\
\hline 30 & 74.8 & 25.2 & 55.6 & 19.2 & Silt Loam \\
\hline 40 & 78.8 & 21.2 & 61.2 & 17.6 & Silt Loam \\
\hline 50 & 76.8 & 23.2 & 61.2 & 15.6 & Silt Loam \\
\hline 60 & 66.8 & 33.2 & 21.2 & 45.6 & Clay \\
\hline 70 & 60.8 & 39.2 & 19.6 & 41.2 & Clay \\
\hline 80 & 62.8 & 37.2 & 21.6 & 41.2 & Clay \\
\hline 90 & 60.8 & 39.2 & 22 & 38.8 & Clay Loam \\
\hline
\end{tabular}




\begin{tabular}{|c|c|c|c|c|c|}
\hline \multicolumn{7}{|c|}{ Table 5: Soil texture of Trial Bore-2 } \\
\hline Depth (ft.) & \multicolumn{5}{c|}{ Soil Texture } \\
\hline & Silt +Clay & Sand\% & Silt\% & Clay\% & Texture Class \\
\hline 10 & 70.8 & 29.2 & 51.2 & 19.6 & Silt Loam \\
\hline 20 & 76.8 & 2.2 & 55.6 & 21.2 & Silt Loam \\
\hline 30 & 60.8 & 39.2 & 39.2 & 21.6 & Loam \\
\hline 40 & 31.6 & 68.4 & 22 & 9.6 & Sandy Loam \\
\hline 50 & 77.6 & 22.4 & 58.4 & 19.2 & Silt Loam \\
\hline 60 & 73.6 & 26.4 & 52.4 & 21.2 & Silt Loam \\
\hline 70 & 41.6 & 58.4 & 31.6 & 10 & Sandy Loam \\
\hline 80 & 41.6 & 58.4 & 30 & 11.6 & Sandy Loam \\
\hline 81 & 31.2 & 68.8 & 21.6 & 9.6 & Sandy Loam \\
\hline
\end{tabular}

\begin{tabular}{|c|c|c|c|c|c|}
\hline \multicolumn{7}{|c|}{ Table 6: Soil texture of Trial bore-3 } \\
\hline Depth (ft.) & \multicolumn{5}{|c|}{ Soil Texture } \\
\hline & Silt +Clay & Sand\% & Silt\% & Clay\% & Texture Class \\
\hline 10 & 73.6 & 26.4 & 56.4 & 17.6 & Silty Loam \\
\hline 20 & 77.6 & 22.4 & 51.6 & 26 & Silty Loam \\
\hline 30 & 79.6 & 20.4 & 62 & 17.6 & Silty Loam \\
\hline 40 & 71.2 & 28.8 & 58 & 13.2 & Silty Loam \\
\hline 52 & 77.6 & 22.4 & 62 & 15.6 & Silty Loam \\
\hline 60 & 22 & 78 & 11.6 & 10.4 & Sandy Loam \\
\hline
\end{tabular}

\begin{tabular}{|c|c|c|c|c|c|}
\hline \multicolumn{7}{|c|}{ Table-7 Soil texture of Trial bore 4 } \\
\hline \multicolumn{7}{|c|}{ Soil Texture } \\
\hline & Silt +Clay & Sand\% & Silt\% & Clay\% & Texture Class \\
\hline 10 & 90.8 & 9.2 & 64.8 & 26 & Sandy clay loam \\
\hline 20 & 83.2 & 16.8 & 51.2 & 32 & Silty clay loam \\
\hline 30 & 82.4 & 17.6 & 50.4 & 32 & Silty clay loam \\
\hline 40 & 70 & 30 & 24 & 46 & Clay \\
\hline 50 & 41.2 & 58.8 & 21.2 & 20 & Sandy clay \\
\hline 60 & 51.2 & 48.8 & 21.2 & 30 & Sandy clay \\
\hline 70 & 91.2 & 8.8 & 46.4 & 44.8 & Silty clay \\
\hline 80 & 94.8 & 5.2 & 76.8 & 18 & Silty loam \\
\hline 90 & 99.2 & 0.8 & 87.2 & 12 & Silty loam \\
\hline
\end{tabular}

\section{VES-08 and Trial Bore-5}

At site VES-08, three layers of low resistivity were discovered, indicating the presence of finely ground materials, such as clay/shale with rare sand and has saline to less saline water-bearing potential. The textural analysis of soil collected from trial bore-5 shows one layer of soil (sandy clay) up to $100 \mathrm{ft}$. in depth (see Table 8). Therefore, the data from the trial bore soil has a low correlation with the VES data. The water collected from trial bore-5 has high salt content, indicated by its high EC and TDS values (see Table 3). This data demonstrates high correlation between VES08 and the trial bore- 5 water data.

\begin{tabular}{|c|c|c|c|c|c|}
\hline \multicolumn{6}{|c|}{ Table 8: Soil texture of Trial Bore-5 } \\
\hline $\begin{array}{c}\text { Dept } \\
\text { Soil Texture } \\
\text { (ft.) }\end{array}$ & \multicolumn{7}{|c|}{} \\
\hline & $\begin{array}{c}\text { Silt } \\
+ \text { Clay }\end{array}$ & $\begin{array}{c}\text { Sand } \\
\text { \% }\end{array}$ & $\begin{array}{c}\text { Silt } \\
\text { \% }\end{array}$ & $\begin{array}{c}\text { Clay } \\
\%\end{array}$ & $\begin{array}{c}\text { Texture } \\
\text { Class }\end{array}$ \\
\hline 10 & 40.8 & 59.2 & 24.8 & 16 & $\begin{array}{c}\text { Sandy } \\
\text { clay }\end{array}$ \\
\hline 20 & 31.2 & 68.8 & 21.2 & 10 & $\begin{array}{c}\text { Sandy } \\
\text { clay }\end{array}$ \\
\hline 30 & 29.2 & 70.8 & 21.2 & 8 & $\begin{array}{c}\text { Sandy } \\
\text { clay }\end{array}$ \\
\hline 40 & 30.4 & 69.6 & 18.4 & 12 & $\begin{array}{c}\text { Sandy } \\
\text { clay }\end{array}$ \\
\hline
\end{tabular}




\section{CONCLUSIONS AND RECOMMENDATIONS}

Excluding sites 13 and 19 all sites lack drinkable water. Water samples collected from bore holes at sites $1,3,5,7$, and 8 , shows saline water because of high $\mathrm{EC}$ and TDS i.e. above WHO limits, which in results validate VES findings.

However, at site 13 (Goth Haji Daad M. Rind Baloch), three layers were discovered with first, second and third layer lie in the high, medium and low resistivity zone respectively. The first layer had depth of $2.9 \mathrm{~m}$ with resistivity value of $17.7 \mathrm{ohm}-\mathrm{m}$. The second ( $38.2 \mathrm{~m}$ deep) and third layer ( $300 \mathrm{~m}$ deep) had resistivity of 6.6 and $1.5 \mathrm{ohm}-\mathrm{m}$ respectively. Since out of three layers only first layer of site 13 lies in the high resistivity zone which indicates availability potable groundwater.

At site 19 (Near Pir Baber Sher village, UC Jhangara-Bajara to Pir Babar Sher village), top two layers had 24.6 and $19.4 \mathrm{ohm}-\mathrm{m}$ resistivity which shows high resistivity zone and ultimately indicates the presence of high-quality groundwater up to $14.2 \mathrm{~m}$ depth. Moreover, at same site third and fourth layer had 6.5 and $3 \mathrm{ohm}-\mathrm{m}$ resistivity which shows medium and low resistivity zone and eventually shows non potable drinking water up to a depth of $300 \mathrm{~m}$.

To conclude, it is found that most of the groundwater at shallow depths at all sites is non potable. Moreover, due to financial and time constraints this study was limited to few bore holes. Therefore, it is recommended to conduct study at deeper depths which may be carried out by increasing the space between the current electrodes and to include enough trial bores to validate the VES findings. Additionally, other water parameters which are not icluded in this study such as (hardness, analysis of different metals, total coliform, e.coli form etc.) must be analyzed.

\section{ACKNOWLEDGMENTS}

The authors would like to thank the Pakistan Council of Research in Water Resources (PCRWR), Lahore for providing the necessary data for this study. In addition, they would also like to thank the U.S Pakistan Centers for Advanced Studies in Water (USPCASW) and Mehran University of Engineering and Technology (MUET) Jamshoro for support and providing a platform for conducting this research.

\section{REFERENCES}

1. Abdullahi M. G., Toriman M. E., Gasim M. B., "The Application of Vertical Electrical Sounding (VES) for Groundwater Exploration in Tudun Wada Kano State, Nigeria”, Journal of Geology \& Geosciences, Vol. 04, No. 01, 2015.

2. Arain M. B., Kazi T. G., Jamali M. K., Jalbani N., Afridi H. I., Shah A., "Total dissolved and bioavailable elements in water and sediment samples and their accumulation in Oreochromis mossambicus of polluted Manchar Lake", Chemosphere, Vol. 70, No. 10, pp. 1845-1856, 2008.

3. WHO, "Health Criteria and Other Supporting Information - Addendum," Guidelines for Drinking Water Quality, Vol. 2, p. 127, 1998.

4. Mastoi G. M., Shah S. G. S., Khuhawar M. Y., "Assessment of water quality of Manchar Lake in Sindh (Pakistan)," Environ. Monit. Assess., Vol. 141, No. 1-3, pp. 287-296, 2008.

5. Kazi T. G., Arain M. B., Jamali M. K., Jalbani N., Afridi H. I., Sarfraz R. A., Baig J. A., Shah A. Q., "Assessment of water quality of polluted lake using multivariate statistical techniques: A case study," Ecotoxicology and Environmental Safety, Vol. 72, No. 2, pp. 301-309, 2009.

6. Channar A. G., Rind M. A., Mastoi G. M., Almani K. F., Lashari K. H., Qureshi M. A., Mahar N., "Comparison Study of Water of Manchhar Lake with Drinking Water Quality Standard of World Health Organization", American Journal of Environmental Protection, Vol. 3, No. 2, p. 68, 2014..

7. Mastoi G. M., Lashari K. H., Palh Z. A., Soomro A. N., Laghari Z. A., Almani K. F., Mastoi G.-eR. A. W., Abbasi A. R., "Water quality assessment of Manchar Lake during the month of August and November 2011 by analyzing selected trace elements", African Journal of Pure and Applied Chemistry, Vol. 8, No. 11, pp. 176-181, November 2014.

8. Ehirim C. N., Nwankwo C., "Quality Assessment 
and Evaluation of Groundwater Potentials in Parts of Buruku and Gboko Local Government Area Councils in Benue State," International Journal of Geosciences., Vol. 07, No. 09, pp. 1064-1073, 2016.

9. Arshad M., Cheema J., Ahmed S., "Determination of lithology and groundwater quality using electrical resistivity survey," International Journal of Agriculture and Biology, Vol. 9, No. 1, pp. 143-146, 2007.

10. Oseji J.O., Atakpo E A, Okolie E.C., "Geoelectric investigation of the aquifer characteristics and groundwater potential in Kwale Delta State, Nigeria", Journal of Applied Sciences and Environmental Management, Vol. 9, No.1, pp. 157-160, 2005.

11. Sikandar P., "Groundwater Management Using Vertical Electrical Sounding Survey and Tubewell Auditing at Farmers' Fields", PhD Thesis, University of Agriculture, Faisalabad, 2010.

12. Reynolds J.M., "An Introduction to Applied and Environmental Geophysics", John Wiley \& Sons, 2011.

13. Ullah Z., Junaid M., Ullah R., "Assessment of Groundwater Strata by Resistivity Survey at Specific Locations in District Buner," Journal of. Earth Science and Climate Change, Vol. 06, No. $10,2015$.

14. Alile O. M., Ujuanbi O., Evbuomwan I. A., "Geoelectric investigation of groundwater in Obaretin - Iyanomon locality , Edo state , Nigeria," Journal of Geology and Mining Research, Vol. 3, No. 1, pp. 13-20, 2011.

15. IS 15736, "Geological exploration by geophysical method (electrical resistivity) - Code of practice [WRD 5: Geological Investigation and Subsurface Exploration]", 2007.

16. Khan G. D., Waheedullah, Bhatti A. S., "Groundwater Investigation by Using Resistivity Survey in Peshawar, pakistan", Journal of Resource Development and Management, Vol. 2, pp. 9-20, 2013.

17. Anomohanran O., "Geoelectrical Investigation of Groundwater Condition in Oleh , Nigeria", International Journal of Recent Research and Applied Studies, Vol. 15, pp. 102-106, April 2013.
"Application of Vertical Electrical Sounding and Horizontal Profiling Methods to Decipher the Existing Subsurface Stratification in River Segen Dam Site , Tigray , Northern Ethiopia," Environmental Earth Sciences, Vol. 3, No. 10, pp. 42-55, 2013.

19. Khalil M. H., "Geoelectric resistivity sounding for delineating salt water intrusion in the $\mathrm{Abu}$ Zenima area, west Sinai, Egypt", Journal of Geophysics and Engineering, Vol. 3, No. 3, p. 243, 2006.

20. Omosuyi G. O., Adeyemo A., Adegoke A. O., "Investigation of groundwater prospect using electromagnetic and geoelectric sounding at afunbiowo, near Akure, Southwestern Nigeria", Pacific Journal of Science and Technology, Vol. 8, No. 2, pp. 172-182, 2007.

21. Bello A. Abdulmajeed, Makinde, and Victor, "All correspondence should be directed to 2 above," vol. 3, no. 2, pp. 36-44, 2007.

22. Yusuf K. A., "Evaluation of roundwater Quality Characteristics in Lagos-City," 2016.

23. Ahmed A. M., Sulaiman W. N., "Evaulation of Groundwater Quality in a Landfill Using Resistivity Survey,” pp. 1-6, 1996.

24. El-Qady G., "Exploration of a geothermal reservoir using geoelectrical resistivity inversion: case study at Hammam Mousa, Sinai, Egypt," J. Geophys. Eng., vol. 3, no. 2, pp. 114-121, 2006.

25. Danielsen J. E., Dahlin T., Owen R., Mangeya P., Auken E., "Geophysical and hydrogeologic investigation of groundwater in the Karoo stratigraphic sequence at Sawmills in northern Matabeleland, Zimbabwe: A case history," Hydrogeol. J., vol. 15, no. 5, pp. 945-960, 2007.

26. ABEM, Instruction Manual, Terrameter LS, ABEM Product Number 333000 95, 2010.

27. Robinson E.S., Coruh C., "Basic exploration Geophysics" John Wiley, 1988.

28. Hassan E., Rai J. K., Anekwe U. O., "Geoelectrical Survey of Ground Water in Some Parts of Kebbi State Nigeria , a Case Study of Federal Polytechnic Bye-Pass Birnin Kebbi and Magoro Primary Health Center Fakai Local Government”, Geosciences Journal, Vol. 7, No. 5, pp. 141-149, 2017.

18. Bairu A., Yirgale G., Gebrehiwot G., 